\title{
POR UMA TEORIA CONTEMPORÂNEA DO ESPETÁCULO: MIMESIS E DESEMPENHO ESPETACULAR
}

\author{
Luis Fernando Ramos
}

\section{Resumo}

Contemporaneamente, com a expansão dos estudos teatrais para os campos da performance e das formas performativas das artes visuais, como a "live art" e os "site specific”, o vídeo e as instalações, bem como as crescentes interfaces com disciplinas como a antropologia, a etnologia e a sociologia, foi se tornando cada vez mais complexo definir este objeto privilegiado de investigação, o espetáculo. A pretensão aqui é tentar recortar melhor este campo, arriscando depurá-lo de um excesso de referências possíveis a fim de definir o que nele seria ontologicamente específico. Na busca desta especificidade tenta-se, por um lado resgatar a noção de espetáculo da generalidade que algumas abordagens o lançaram ao mesmo tempo em que se quer refazer a história conceptual que vai originar a sua acepção moderna e propor a retomada da noção de mimesis, e um seu desdobramento, a noção de desempenho espetacular, como produtivas para operar a leitura da cena contemporânea.

Palavras-chave: espetáculo, performance, mimesis e desempenho espetacular

\section{Abstract}

Contemporarily, with the expansion of theatre studies towards the fields of Performance art and other visual arts engaged with performativity, as the "live art" and the "site specific", the video and the art exhibition, as well the crescent intermingling with disciplines as the anthropology, the ethnology and the sociology, it became more and more complex to define this privileged object of investigation - the performance. The intention here is to try to reshape better this field, risking purifies it from the excess of possible references in order to define what is ontologically specific of it. In this search will be tried, for one side, to regain the notion of performance from the generality which some approaches had launched it, at the same time that is aimed to remake the conceptual history that would originate its modern meaning. By the way it is proposed to rethink the concept of mimesis and one extension of it, the notion of performative performance, as productive to operate the reading of the contemporary scene.

Keywords: theatricall performance, performance, mimesis, performative performance

A idéia de que contemporaneamente tudo é espetáculo e que a realidade tornou-se ela própria uma representação deve ser refutada. Ela impede que nos detenhamos sobre o espetáculo e o espetacular como instâncias ontologicamente distintas da vida de todos os dias e da realidade humana. Da mesma forma,

${ }^{\text {IProfessor da }}$ Universidade de São Paulo 
o fato de mimetizar outrem ser um dos instintos humanos, revelando uma pulsão irresistível à repetição, não indica que todas as ações humanas sejam miméticas, nem que toda mimese seja necessariamente imitativa.

Os eventos, sociais ou psíquicos que abundam na realidade não se confundem com toda a gama de manifestações artísticas contemporâneas - sejam elas presenciais, como instalações, performances, encenações, ou projetadas, como cinema, vídeo, fotografias -, portadoras de um incontornável caráter representativo, espetacular, de coisas que se dão a ver e de alguma maneira reapresentam e repetem em novos termos o mundo, ou a vida.

É preciso, pois, estabelecer um recorte claro, que se admita, inclusive, como artificial e estratégico, para delimitar a análise proposta àqueles fatos e acontecimentos que têm em comum a intenção de se apresentarem a outrem, se darem a ver como espetáculo com alguma intencionalidade. Esta pode ser mais convencional, respeitando os cânones de alguma forma artística, ou negar a própria arte enquanto possibilidade de linguagem. De qualquer modo o que definiria a sua espetacularidade seria o fato de ser produzida para ser vista. As hipóteses de que nenhuma produção humana escape de ser transformada em mercadoria para a circulação e consumo, ou de que esteja necessariamente contaminada por pulsões libidinais inconscientes, não anularia essa intencionalidade humana de gerar algo além da realidade ou natureza. Quer dizer há uma diferença ontológica entre o que se dá a ver por si e o que é visão produzida para afetar.

Mesmo aqueles fatos e acontecimentos intencionalmente artísticos que se negam a cumprir o cânone da expressão artística, ou se recusam a configurar qualquer representação, como abundam os exemplos desde as vanguardas históricas até tendências contemporâneas, da arte minimalista e conceitual, ou, mesmo no campo das artes cênicas, certas experiências assumidamente não miméticas, seriam pertinentes a esse campo do espetacular. Para efeito dessa análise todo e qualquer acontecimento, ou fato cultural, que se insira no processo de fruição artística, independente de estar ou não vinculado ao sistema de mercado da arte, será considerado como intencional, a despeito do programa do artista em questão, e de sua maior ou menor inserção nos fluxos de produção e recepção da arte.

Fica claro que tal proposição ignora perspectivas como as que percebem uma homogeneização dos processos sociais e econômicos a condicionar toda e qualquer manifestação cultural (Teoria Crítica), ou aquelas percepções de cunho psicanalítico que localizam em toda e qualquer manifestação humana, mas principalmente nas estéticas, pulsões anímicas, ou de origem traumática, 
nos psiquismos humanos (Lyotard). Estariam excluídas estas duas raízes que remetem a Marx e Freud respectivamente, já que comprometem a própria idéia de uma intencionalidade realmente ativa, que estaria sempre submetida ora às circunstâncias da ideologia dominante, no caso do primeiro, ora às pulsões eróticas e de morte, no caso do segundo. Estar-se-ia mais próximo de uma terceira via, ou do antiniilismo niezstcheano, em que se assume a possibilidade da linguagem produzir formas libertadoras.

Mas sem precisar entrar em um campo exterior ao da própria expressão espetacular, e nos restringindo a ela, vale dizer que não há como não reconhecer, digamos, uma pulsão de ainda apresentar o mundo em qualquer uma das manifestações espetaculares contemporâneas, mesmo quando fazem da discrição e do silêncio suas vocações.

Admitido isso, e para não pasteurizar todas as manifestações sob o manto da representação, repetindo os procedimentos da teoria crítica ou da teoria das pulsões eróticas, há que buscar procedimentos analíticos, que, para além da inocência sobre uma utópica representação não representacional, distinga entre as manifestações espetaculares, por exemplo, aquelas que venham a atualizar potências do mundo insuspeitas e não simplesmente reapresentar potências já explicitadas na história da arte.

Um segundo passo será distinguir nestas manifestações absolutamente novas seus processos constitutivos, de modo a compreender como articulam sua efetivação sobre os receptores. Essas operações, mais do que controlar aqueles procedimentos para repeti-los, conseqüência inevitável, contudo, visaria explicitar aos receptores a riqueza construtiva ou particularidade de ineditismo que aquela obra ou espetáculo apresenta.

Como a ciência, que não se coloca um limite em seu desenvolvimento, a arte, a despeito de sua dependência de alguns níveis de redundância (a que a própria ciência não se furta) terá sempre alguma olhar insuspeito e perspectiva nova a revelar sobre a condição humana e os contextos históricos em que esta condição humana se expressa.

\section{Do mythos ao opsis}

Em termos teatrais, pensar o espetáculo contemporaneamente obriga a diferenciar o que nele está afeito ao dramático, funcionando nas correias de transmissão narrativa do tempo e espaço ficcionais, e confundido com a dita carpintaria teatral, do que é expressão de sua condição intrínseca, material e tridimensional, de superfície que se dá a ver e é tempo-espacialmente indissociável do aqui e agora. 
Não é a mesma coisa pensar a cena e sua dramaturgia implícita como uma operação dramática de concatenação e fortalecimento de uma narrativa anterior - literária ou oral, subjetiva ou coletiva - e pensá-la como poiesis de algo concreto, produção de visualidade e materialidade autônomas de qualquer referente anterior, ou, mesmo quando referencial, estruturada a partir de planta arquitetônica, mapa de um lócus a corporificar, contorno holográfico. Em geral essa diferença se oculta, subsumida na idéia da funcionalidade narrativa, que coloca a construção da visualidade cênica subordinada à construção do sentido. Reconhecê-la é apontar uma tensão entre dois modos de pensar o que se convencionou chamar de dramaturgia da cena, desde que Marco de Marinis, em 1978, propôs a idéia de que a cena tem uma textualidade própria que suplanta seus antecedentes literários e que, como tal, deve ser o objeto central da investigação sobre o teatro (MARINIS, 1978). Na verdade, esta tensão está presente já nas primeiras teorizações sobre o teatro no ocidente.

Quando Platão, no livro três de "A República”, formulou a diferença entre o que chama de modos diegético e mimético de apresentação ficcional, $o$ primeiro associado à pura narrativa $e$, o segundo, às ficções que se apresentavam através de atores, já se pontuava esta oposição (PLATÃO, 2006). O que se entendia como mimético nessa comparação, e que podia ser também chamado de dramático, trazia já fundidas as dimensões literária e espetacular do fenômeno teatral, mas seria recriminado em Platão mais pelo seu caráter performativo, do que pela sua condição de narrativa dramática. A estrutura dialógica abrigada na forma escrita e, assim, minimizada, era mais aceitável que quando apresentada como espetáculo, implicando em lançar mão de atores.

Já na "Poética” de Aristóteles, quando ele disseca o fenômeno da tragédia ateniense do século $\mathrm{V}$, a tensão reaparece na diferença que se estabelece entre um elemento mais literário da tragédia - sua estrutura narrativa, ou trama -, o mythos, e o elemento da materialidade e visualidade do espetáculo trágico - o opsis. Tornou-se quase um chavão apontar a Poética como um tratado sobre o dramático enquanto fenômeno literário, a partir de uma suposta predileção de Aristóteles pelo mythos em detrimento do opsis, com base na hierarquia analítica estabelecida entre os seis elementos que formam a tragédia. Estudos mais recentes têm deixado claro que essa interpretação é uma redução insustentável, e que, a despeito dessa hierarquização, o tratado abrange, de fato, o fenômeno do espetáculo trágico (SCOTT, 1999). De qualquer modo, quando Aristóteles recomenda que os efeitos mais significativos da tragédia, a afetação da piedade e do terror no público, bem como sua finalidade última, a catarse, serão obtidos mais intensamente pela forma com que o poeta dramático engendrar sua trama, e trouxer o espectador preso aos seus sucessos e insucessos, do que à forma como o cenógrafo construir, objetivar e materializar a cena concreta, ele está não só revelando uma compreensão possível do fenômeno cênico, como 
identificando um aspecto crucial na relação, em geral misturada e indistinta, das narrativas literária e espetacular. Elas se apresentam enquanto espetáculo, mas guardam, simultaneamente, uma estrutura literária que antecede essa apresentação. Distinguir esses dois planos do dramático, o estritamente literário e o puramente espetacular, e percebê-los em suas especificidades, analiticamente isolados, já era um avanço estupendo. O fato de que, como se está sugerindo, no teatro contemporâneo estes dois planos possam estar explicitamente dissociados não diminui a importância desta distinção.

Outro passo importante nessa trajetória foi dado, no século XVIII, por Diderot quando, em seu "Discurso sobre a Poesia Dramática" (DIDEROT, 2006), resgatou a "Poética" de Aristóteles das malhas deformadoras do neoclassicismo e valorizou a dimensão visual da composição dramática. O neoclassicismo tinha sido uma leitura radical da "Poética", na medida em que o elemento da trama, ou do mythos, foi hiper valorizado a ponto de se gerar a idéia das unidades de tempo e de lugar como imprescindíveis. Como se sabe, Aristóteles só recomenda a unidade de ação, e essa suprema deformação de unidades obrigatórias é exemplar de um ponto de vista em que o viés literário se impunha soberano na consecução narrativa, reduzindo o espetáculo a mero suporte físico do drama. Curiosamente, as tragédias de Racine e Corneille, quando imaginadas nos contextos de suas encenações do século XVII, nos soam, na perspectiva do naturalismo do século 20, como extremamente teatrais, mas a percepção revolucionária de Diderot, incomodado com o artificialismo que seus alexandrinos exalavam, apontava precisamente para o caráter espetacular do teatro, que aquela valorização excessiva do mythos sobre o opsis ocultava. O aspecto interno da dramaturgia da cena, sua estrutura literária e ficcional, sufocava sua dimensão externa, ou suas potencialidades semânticas enquanto espetáculo. É assim que Diderot vai, por exemplo, apontar a importância do dramaturgo visualizar o espetáculo no momento da composição dramática, e enfatizar, sobremaneira, o peso definitivo que os corpos dos atores, e seus respectivos movimentos, têm na realização do drama. Ainda não havia uma dissociação acabada entre os planos do literário e do cênico, que já tinham sido distinguidos na análise de Aristóteles. Diderot pontuava essa dualidade, mas a subordinava a um projeto cuja realização pressupunha as prerrogativas do dramaturgo.

Talvez, essa separação que alimenta contemporaneamente a ambigüidade do conceito de espetáculo e permite, inclusive, proposições como a do pós-dramático, tenha se expressado pela primeira vez, plenamente, na conceituação de Mallarmé sobre o teatro. Inicialmente, nas críticas que faz à ópera de Wagner, por esta fundir as dimensões física e material da música e dos atores aos aspectos ficcionais e dramáticos, e, depois, em seu projeto mais ambicioso, de um teatro em que as dimensões do silêncio e do gesto libertados do sentido ficcional se bastariam autônomos e absolutos. O que 
é fascinante em Mallarmé é que em sua visão, simultaneamente, a literatura ganha autonomia da ficção dramática e o espetáculo deixa de se submeter a esta mesma ficção. De um lado, a literatura deixa de se prestar a confundirse com o dramático na dimensão teatral, já que, para ele, o livro é a grande arte e está em perfeita oposição ao dramático. Ainda caberia ao literário um aspecto performativo, como o que sonhou se manifestaria na realização do seu projeto do “Livro”. Mas este rito literário, necessariamente, não implica mais em concessões à ficção dramática. O espetáculo, por sua vez, também se libertaria desse jugo do drama, passando a ser tecido, em hipótese, só com os corpos e a música, dissociado de sentidos prévios e de qualquer vínculo anterior. É nessa medida que o teatro imaginado por Mallarmé configura-se, literalmente, como um oxímoro, ou seja, uma unidade dual em que a literatura e o espetáculo, expurgando a ficção dramática, se radicalizam alternativamente no puramente literário e no puramente espetacular. Nos termos propostos, na reflexão de Mallarmé, além do literário e do cênico serem depurados do dramático, mythos e opsis dissociam-se completamente (SHAW, 1993).

Essa dissociação conceitual que se depreende dos poucos textos de Mallarmé sobre a teatralidade, ocorre, historicamente, no momento em que emerge o drama naturalista, ou o que retrospectivamente seria chamado de “drama moderno". É uma fase não só de grandes dramaturgos (Ibsen e Strindberg) como de valorização do aspecto literário dessa produção, veiculada às massas na forma de livros. Isto talvez explique porque, no fim do século 19, tanto as encenações naturalistas como as simbolistas, por mais distintas que fossem efetivamente no peso que atribuíam ao aspecto ficcional - muito mais abrandado na perspectiva simbolista - não incorporassem essa dissociação completa que Mallarmé tinha imaginado possível. Isto só ocorrerá, por exemplo, já no início do século 20, como fruto de teorizações como as de Gordon Craig. Profundamente inspirado em Mallarmé, ele vai se dar ao trabalho de pensar sobre o puro espetacular, ou sobre o teatro como uma arte totalmente autônoma da literatura e com suas próprias leis e princípios. Craig chegou a escrever uma dramaturgia para teatro de bonecos, O Drama for Fools - dezenas de peças, nunca publicadas, de um conjunto planejado de 365, uma para cada dia do ano. (RAMOS, 1999) Destinada às crianças, essa produção não se confundia com seus projetos cênicos e é ele que se encarrega em esclarecer isso quando diz que essa dramaturgia para os "pequenos bonecos" não tem nada a ver com a nova cena sonhada e que tinha no "ubbermarioneten", ou super marionete, o seu ator principal. Interessa aqui ressaltar a consciência de Craig sobre a diferença crucial entre encenar por meio da composição de ações dramáticas e criar uma cena diretamente, sem qualquer mediação literária. O projeto de Craig teve na construção de maquetes das "mil cenas em uma” volumes e telas movimentados vertical e horizontalmente na arquitetura da 


\section{Urdimento}

cena, como uma música que ganhasse corpo e tridimensionalidade no espaçoa sua concretização virtual. (CRAIG, 1923) A partir daí, definitivamente, já se pode falar de uma "poética da cena”, em que o opsis torna-se o elemento central, em detrimento, ou para além da "poética do dramático”, legada por Aristóteles e ancorada na dimensão literária do fenômeno cênico, ou no mythos.

O teatro da segunda metade do século 20, a partir de Artaud e Brecht, mas principalmente com Beckett e Kantor, não fez outra coisa senão atualizar esta autonomia potencial do espetáculo frente ao drama. Alguns criadores como Robert Wilson foram radicais na perspectiva do opsis e concretizaram espetacularmente os sonhos de Mallarmé e Craig. Mais recentemente, Romeu Castellucci vem atualizando esta tradição de uma cena absolutamente autônoma. Outros, como Robert Lepage, propõem reatamentos em novos termos, com composições dramáticas não necessariamente mediadas pela literatura, mas articuladas já como cenas narrativas, numa poiesis em que mythos e opsis se reconciliam. É nesta direção que parecem caminhar, no Brasil, a maioria dos grupos experimentais em seus processos hegemonicamente colaborativos. A cena passa a narrar histórias por si e a dramaturgia da cena torna-se um modo de operar a construção dramática em novos parâmetros: mais distanciados da literatura, mas, ainda, presos, essencialmente, à idéia de uma trama conseqüente de ações. A alternativa radical, e desafio continuam sendo pensar o espetáculo como puro opsis, matéria concreta tornada visível, textura. Nesta hipótese, criar uma cena, menos do que tecer um novelo de ações, como sugere a metáfora tradicional da criação ficcional e dramática, é constituir uma semântica de superfícies, tessitura de cores e imagens, apresentação de objetos não previamente identificados. A cena se articula na organização sintática das diversas texturas, que se alternem em transparência, opacidade, rugosidade, relevo ou outras quaisquer categorias da superficialidade e forma dos corpos concretos que possam existir. Se ainda há mythos, ele aparece totalmente dissociado do opsis, atuando autônomo e em paralelo, como teria sonhado Mallarmé.

\section{Da linha à superfície}

A cultura contemporânea, já apontou Vilém Flusser há trinta anos², é muito mais fundada numa percepção áudio-táctil do que vinha sendo desde a invenção da imprensa, quando, com a especialização do olhar para a leitura, tornou-se crescentemente focada na linha e no sentido. A opinião converge com a perspectiva de movimentos como o minimalismo nos Estados Unidos e o neoconcretismo no Brasil, no início dos anos sessenta do século passado, de propor a obra de arte como objeto e ignorar os limites entre imagem e tela, ou entre esta e a moldura. Passou a ser buscado distinguir na obra a sua condição de objeto, ou o fato de que, antes de ser uma figura, uma mancha ou uma cor, a obra é uma materialidade. Essa opção encontrou no projeto da arte conceitual,

${ }^{2}$ FLUSSER, Vilém. "Line and Surface" Writings, Adreas Ströhl. Editor, Minneapolis/London: University of Minnesota Press, 2002. 
${ }^{3}$ GUINSBURG, J. "O

Teatro como Tal:

Everinov",

Stanislávski,

Meierhold \& Cia.,

São Paulo:

Perspectiva, 2001.

${ }^{4}$ FREID, Michael.

Art and Objecthood: essays and reviews. Chicago: University of Chicago Press, 1998. ${ }^{5}$ FÉRAL, Josette. "Theatricality": The Specificity Theatrical Language, Substance, vol.31 2\&3, Madison: University of Wisconsin Press, 2002. ou da primeira reverberação da obra de Duchamp depois de sua morte, um aliado fundamental e transferiu a questão da arte de dentro da obra e de sua lógica interna, como tinha ocorrido na pintura concreta, para o processo de fruição, ou para a significação que adquirirá no seu encontro com o público. Quanto mais essa recepção ativar a obra propondo-lhe novas modulações, mais ela terá atingido sua razão de ser. No limite, já não haverá propriamente uma obra, ou ela se tornará o próprio espectador em sua capacidade de produzir uma resposta a partir de um esvaziamento absoluto que o artista venha a promover, livrando a obra, inclusive, da sua condição de objeto, ou, constituindo-a como tal, apenas, enquanto eco na fruição do seu observador. Na desambição de narrar uma história definida e procurando na interlocução com o público, mais do que um efeito, alguém que possa estabelecer um sentido próprio e fazer valer aquele acontecimento. É um projeto de espetáculo que abdica do centro narrador e se entrega às potências dos espectadores para que formulem soluções e sínteses. Interessa aqui pensar essa tendência a partir do conceito de teatralidade, tendo claro as duas vertentes distintas em que ele se manifesta. A primeira nascida no âmbito da reflexão sobre o teatro e o espetáculo, que remete a Aristóteles (opsis), passa por Evreinov ${ }^{3}$ e ainda reverbera contemporaneamente, por exemplo, em Ferál ${ }^{4}$. A segunda, construída na perspectiva da crítica de artes plásticas, para diferenciar o projeto da pintura modernista daquele que o sucede e que de algum modo antecipa a cena contemporânea. Neste último caso o nome referencial é Michael Fried. Contrapondo-se aos minimalistas norte-americanos, Fried vai defender, em 1968, no célebre artigo "Art and objecthood”, que ao eliminar a autonomia que a tela ou a escultura gozavam no modernismo eles promovem uma rendição da arte ao teatro, ou à idéia de que a realização da obra depende do público processar a sua materialidade bruta e atribuir-lhe um significado. ${ }^{5} \mathrm{~A}$ palavra teatralidade é utilizada aqui pejorativamente, para denotar a submissão das artes da pintura e da escultura ao confronto com o observador. Quando o próprio Fried retoma, na década de noventa, a crítica proposta nos sessenta reafirma sua posição, acrescentando que na época nunca tinha imaginado que os efeitos nocivos da teatralidade pudessem ter chegado tão longe. Não há como negar, aquela tendência que ele localizava na arte minimalista se expandiu e hoje predomina no panorama das artes visuais contemporâneas.

Ao mesmo tempo, a crítica de Fried à teatralidade deve ser contextualizada como mais um capítulo da tradição de antiteatralidade que se constituiu, desde o fim do século 19, no campo do teatro. Desde a crítica de Nietzsche ao projeto de ópera Wagneriano, passando pelas propostas radicais de Mallarmé, Alfred Jarry, Gertrude Stein, futuristas italianos e dadaístas, pode-se ler a história do teatro no século 20 na perspectiva da antiteatralidade. Antonin Artaud e Bertolt Brecht, dois vetores do teatro na segunda metade daquele século, se inserem nessa tradição, bem como os desdobramentos que se sucedem a partir da década de sessenta, com Grotowski, os happenings e a 
performance, e o panorama dos últimos trinta anos, que vem sendo caracterizado atualmente como pós-dramático. O que interessa pontuar aqui é o paradoxo que a aproximação da crítica de Fried dessa linhagem de uma teatralidade contra o teatro sugere. Ao identificar como teatralidade a tendência das artes visuais procurarem cada vez mais a resposta do público, atribuindo-lhe uma pulsão demagógica que comprometia a autonomia da obra, ele se inseria nesta tradição de um teatro contra o teatro. Mas, simultaneamente, essa percepção apontava um deslocamento das artes da pintura e da escultura de uma situação contemplativa para uma performativa, em que a obra e seu observador eram mobilizados a interagir. O panorama das artes visuais contemporâneas confirma largamente a percepção de Fried, ainda que o caráter purista de sua crítica, e a superficialidade com que utiliza o conceito de teatralidade, enfraqueçam seu argumento de fundo. $\mathrm{O}$ que aconteceu, a despeito dos preconceitos de Fried, é que, efetivamente, as artes visuais perderam aqueles contornos rígidos que emolduravam obras em paredes e abriram-se às práticas de atualização presencial na relação com o público que sempre foram características das artes cênicas. O espetacular, ou aquilo que se dá a ver e afeta, tornou-se moeda comum a todas as artes contemporâneas, e, mais do que a teatralidade, que aponta para um campo específico, a performatividade passou a ser um conceito operador que dá conta dessa realidade abrangente, em que literatura e música, artes visuais e plásticas, teatro e performance convivem, privados de fronteiras, em fluxos de influências e contra-influências.

Manifestações no campo das ditas artes visuais - instalações, performances, site specifics - buscam cada vez mais o corpo a corpo com o público, enquanto espetáculos teatrais operam na perspectiva contemplativa, de abandono das narrativas dramáticas, estruturadas em ficção e personagens, e de exposição da cena com imagens abertas cujo desenho, a ser decodificado pelo espectador, não se oferece de pronto nem interage diretamente. Os campos se mesclaram e se estranharam. A pintura e a escultura são substituídas enquanto suportes por práticas espetaculares de apresentação ao vivo diante de espectadores, e o teatro, muito afastado do drama, se torna plástico, visual, eventualmente transposto para telas e monitores, ou "instalado" em espaços expositivos, e menos presencial. É uma arte que, a partir dos anos 60, dá as mãos ao espectador para estabelecer uma parceria em sua concretização. Explodem-se os suportes e formatos tradicionais para que as obras se coloquem aos olhos e corpos dos observadores e em seus próprios espaços de trânsito e convivência.

Contemporaneamente, pois, as artes visuais e cênicas compartilham a assunção do espectador/observador à condição de figura central do processo artístico, atuando como um verdadeiro formulador de obras. Seja no viés das exposições e das instalações, seja no âmbito dos espetáculos e das narrativas literárias, há claramente esta demanda. Nesse sentido, dois campos convergem 
na demanda por um espectador mais ativo: um mais próximo do teatro na sua estrutura de articulação contemplativa, que implica um distanciamento do espectador para observar e produzir uma possível narrativa, e outro mais performativo, em situações em que os atuantes se aproximam do público e interagem com ele permitindo que interfiram diretamente na narrativa em curso. Nos dois casos, o centro irradiador da formação de sentido é o espectador, seja permeado por imagens distanciadas seja tocado por corpos aproximados.

No primeiro grupo apresentam-se formas variadas de contemplação. Pode ser pelo enquadramento da caixa cênica, mas com um tempo dilatado de observação, fora dos padrões dramáticos. Assim, o espectador constrói seu caminho pelas imagens cênicas. Ou pode ser no parâmetro da instalação, oferecendo-se em um discurso lírico, ou com uma narrativa de romance, com um discurso mais aberto e polifônico e demandando uma constante movimentação do espectador.

Quando a linguagem espetacular deixa de ser percebida linearmente, como um significante que remete a um significado latente preciso, e quando quase tudo se torna latência, significados errantes, de superfície, a serem configurados de forma distinta por cada observador, a crítica de arte perde um de seus vetores operativos, a exploração da forma e do conteúdo das obras. Imateriais e dependentes dessa interação com o observador para se constituírem, as obras tornam-se jogos abertos, cujas regras, a cada vez, ou a cada apresentação, são propostas novamente. Curiosamente, essa perspectiva evoca uma das chaves da estética Kantiana e mostra sua vitalidade conceitual. Se uma noção como a do "belo" perdeu-se no modernismo, e a autonomia absoluta da obra, consagrada na arte concreta, foi superada em correntes como o minimalismo e o neoconcretismo, a formulação de Kant quanto ao "livre e harmonioso jogo da imaginação e do entendimento" adquire na cena contemporânea (aí entendidas todas as manifestações espetaculares na amplitude das artes visuais e performativas) uma pertinência notável. A idéia do espectador como o lócus formulador da obra, articulada a partir da combinação de sua percepção racional e de sua potencialidade imaginativa, e consubstanciada em um processo lúdico, descreve à perfeição muito do que a contemporaneidade vem propondo como arte. Retomando a proposição de Flusser, quando percebe uma crescente presença da oralidade, e das percepções áudio tácteis, nas formas contemporâneas de fruição das linguagens, poder-seia também reconhecer um claro abandono da linha, enquanto veio por onde escorrem as possibilidades de leitura, e uma adesão às superfícies. A metáfora mais adequada para descrever os novos modos de fruição propostos é, talvez, a dos campos de força, em que pulsões sensórias de vários níveis competem entre si, opondo leituras instáveis e gerando narrativas ilimitadas. 
Um outro modo de vê-las e compreendê-las é pensar numa teatralidade expandida para além do teatro, em que a relação presencial que caracterizava o espetáculo se torna pressuposto de todas as artes. Porém, ao contrário do que propôs Fried, não é que as artes se tornem teatro, mas, sim, que passem a só se definir e justificar imiscuídas na vida do observador. O próprio teatro lançado na aventura de se pensar como objeto não identificado deixa de se oferecer graciosamente às leituras e se propõe como enigma, despertando o espectador do sono dogmático da ficção fechada. A cena se torna uma narrativa possível à espera de narradores que possam, a cada vez, e numa perspectiva particular, contá-la a si próprios. A verossimilhança não é mais previamente construída e testada na sua potência de convencer, mas é construída intimamente pelo leitor/espectador de acordo com suas próprias chaves de leitura.

\section{Mimesis e desempenho espetacular.}

A predominância do opsis sobre o mythos no teatro contemporâneo, que se constituiu ao longo de todo século 20, e, na primeira década do século 21 , configura uma teatralidade expandida para todas as artes performativas. Mesmo representando uma mudança de paradigma frente à reflexão aristotélica da "Poética", não implica necessariamente no esgotamento de uma noção de mimesis como conceito operador. Ao contrário, exatamente porque as fronteiras entre artes como o teatro, a performance, a dança e a chamada "live-art", para não falar em todo campo das artes visuais que transcendeu os suportes tradicionais da tela e da escultura, e transformou as galerias e museus de espaços expositivos em espaços não convencionais de encenação, ou em espaços de encenações não convencionais (quer dizer, não dramáticas), o conceito, tomado em seu sentido de apresentação, ou reapresentação, repetição do mundo ao mundo, ou do homem ao homem, pode ser retomado. É claro que em Aristóteles, e por isso ali o mythos era o elemento central da tragédia, tratava-se de estabelecer um discurso pleno de causalidade que implicasse em um reconhecimento e numa adesão racional ao que se reconhecia. $\mathrm{Na}$ nova configuração, que estamos identificando como a de uma teatralidade expandida, de pura visualidade, de superfícies e cores, e de fruições áudio tácteis e percepções sensórias não codificáveis, se ainda há mythos implícito - porque, afinal, sempre haverá algum referente possível em qualquer imagem, ainda que esta seja simplesmente um simulacro - o elemento preponderante será o opsis, e as noções de efeito e de reconhecimento, ou de eficácia dessas operações com vistas a qualquer finalidade existente terão que ser repensadas. Assim, o sentido de atualização de uma potência latente implícito a mimesis, e a noção de poiesis articulada à de teckné, em última instância a de produção de alguma linguagem, podem muito bem acolher todas estas formas expandidas de teatralidade, ou de acontecimentos performativos e espetaculares eminentemente não dramáticos. 
Eles já não privilegiam o mythos e preponderam em seus discursos como opsis, ou espetáculo. Em busca de um conceito que sem as implicações históricas e remissivas da mimesis, capturasse seu sentido primitivo e atualizasse sua presença na produção contemporânea, opta-se pelo binômio "desempenho espetacular”. Ele apanha a idéia do espetáculo como centro gerador de ações a serem percebidas, e não necessariamente reconhecidas, ao mesmo tempo em que o articula a um gradiente de intensidades possíveis. Não é necessário reter a noção de reconhecimento e de eficácia pela via da compreensão racional para admitir-se a imensa gama de desempenhos possíveis em cada evento espetacular diante de seus espectadores. Aristóteles no livro três da "Retórica", que pode ser lido como sua teoria do espetáculo, já advertia que, a despeito da importância decisiva do silogismo lógico na concretização de uma ação persuasiva, há uma inevitável influência do que entendia como elementos externos na efetivação de um discurso, ou no seu êxito persuasivo. Era nesse mesmo sentido que ele minimizava a influência da cenografia e das máscaras na realização dos efeitos da tragédia, ou catarse, não sem deixar de reconhecer que elas participavam dessa efetivação. Por tudo isso, quando se admite, contemporaneamente, a prevalência da superfície sobre a linha, da cor e da sonoridade bruta sobre a figura e o desenho melódico, do opsis sobre o mythos, encaminha-se uma possibilidade de pensar o espetáculo em sua realidade bruta, material e tridimensional e capaz de ser um agente vigoroso na atualização das potências do mundo. Desse modo, quando se pensa em desempenho espetacular não se está abrangendo qualquer ação humana que se deixe ver, mas, sim, todas aquelas ações humanas que se pretendem construções previamente preparadas para afetar espectadores, ou seja, aquelas que envolvem mimesis de ações a partir de uma, ou várias teknai. Diante deste universo limitado de eventos, todos os espetáculos que voluntariamente se apresentam como tal para afetar espectadores - e não tudo que é performativo na vida humana - se tenta estabelecer um parâmetro de avaliação da qualidade deste efeito, ou de quanto ele, de fato, atualizou uma potência antes inexistente, ou que era anterior a sua realização e restava latente como possibilidade.

Por exemplo, podemos considerar que uma apresentação de patinação artística no gelo, uma fonte de água com programa de rotina pré-preparada, um espetáculo de circo e um espetáculo de Romeu Castellucci têm em comum, serem produções espetaculares do engenho humano, dotadas de técnicas específicas cujos efeitos poderão ser constatados na perspectiva de seu desempenho frente a seus espectadores. Estes exemplos nos interessam porque suas leituras ou fruições compartilham um distanciamento do mythos, ou de qualquer história ou narrativa oculta, e se afirmarão preponderantemente no desempenho de seus realizadores diante dos olhos do público. Mas além dessa semelhança, eles se diferenciam por possuírem antecedentes de naturezas distintas. A 


\section{Urdimento}

patinadora será escrutinada pelos juizes por sua capacidade de realizar com a maior precisão e graça alguns movimentos pré-convencionados, assim como os designers dos jatos de água da fonte terão o compromisso de encantar platéias de parques ou centros de compras, a partir de repetições e variações disponíveis à tecnologia existente. Nestes dois primeiros casos, apesar da preponderância do opsis sobre o mythos, ainda há uma carga de previsibilidade que encaminha necessariamente as leituras - os movimentos rotineiros obrigatórios nas competições de patinação e as limitações implícitas à sintaxe de movimentos de água jorrando no caso das fontes. O terceiro exemplo, do circo, se tem como princípio a atualidade do risco iminente de falhar - por exemplo, nos casos do trapézio ou da performance envolvendo animais - pressupõe sempre um alto grau de redundância típico dos gêneros artísticos que se cristalizaram e cujos formatos tornaram-se molduras constritivas, já que os seus espectadores buscam exatamente reencontrar aquele desempenho já conhecido. ${ }^{6} \mathrm{Em}$ mais do que qualquer outra forma espetacular, no circo vale o conceito de desempenho, pelo que implica de atualização de desafios aos limites humanos, nisso se assemelhando às disputas do atletismo olímpico. Mas, ao mesmo tempo, esta condição limita as possibilidades de transgressão ou de um espetáculo que surpreenda absolutamente, e cuja linguagem se apresente aos espectadores como algo que nunca antes foi visto. Tais características só se encontrariam, entre os quatro exemplos cogitados, na "Tragedia Endogonidia” da Cia Rafaello Sanzio, de Romeu Castellucci, com seus onze espetáculos em que, cada um, apresentava cenas nunca antes vistas, fortemente construídas pelas imagens e pela sonoridade, e em que o mythos, sem dúvida ainda presente, estava totalmente subsumido pelo opsis, principal fonte de leitura e de fruição. ${ }^{7}$ O desempenho espetacular neste caso, não poderá ser avaliado de acordo com regras prévias, como no caso da patinação, ou por padrões decorativos consagrados, como no caso da fonte. Tampouco se restringe a questões como as do cumprimento de rotinas quase impossíveis como no circo (se bem que muitas ações da "performance art"envolvam riscos físicos tanto quanto o circo). Mais provavelmente, o que estará ou não afetando e efetivando uma eventual mimesis, no sentido do apresentado se fazer verossímil como algo pertencente ao mundo, ou como atualização de alguma potência do mundo, não será nenhuma das alternativas citadas, nem a compreensão de uma história, ou o reconhecimento de referentes de um mundo dado como real por uma cognição racional. O que se efetivará ou não no desempenho dos espetáculos de Castellucci será a percepção daquele discurso espetacular enquanto tal, mensurado pelo grau de precisão com que se apresente aos sentidos no que diz respeito a sua visibilidade, superfície, sonoridade e consistência, enquanto matérias que se apresentam inaugurais, sem qualquer parâmetro auxiliar além de suas presenças concretas. Nestes planos, ou níveis de recepção, haverá espetáculos que afetarão com mais intensidade que outros, e provocarão leituras áudio

\footnotetext{
${ }^{6} 0$ chamado circo novo, de que o Circo du Soleil é o exemplo mais contumaz, ampliou as rotinas e as possibilidades espetaculares do circo, mas não a ponto de expandi-las, ao imprevisível e impensável, até para não abandonar a condição de circo, ou seja, as constrições do gênero. Um exemplo semelhante seria 0 da ópera, em que, mesmo com as inovações sensacionais dos encenadores contemporâneos, nunca se rompem alguns limites demarcadores do gênero.

${ }^{7}$ Os onze espetáculos da Tragédia Endogonidia foram apresentados entre 2002 e 2004 em dez cidades européias (duas vezes em Cesena) com 0 apoio de vários festivais e instituições culturais.
} 
tácteis mais ou menos efetivas. Este exemplo poderia ser substituído por muitos outros espetáculos e instalações artísticas contemporâneas. O que importa ressaltar é que nestes casos, em que os eventuais antecedentes referenciais são quase inexistentes, ou ignotos pelo espectador, resta-lhes a pura visualidade e sonoridade da presença viva, ou imagética (no caso de vídeos e cinema) para afetá-lo. Será que ainda assim há desempenho espetacular a ser avaliado, ou mensurado? Parece que sim, pois haverá sempre um desempenho intrínseco e inevitável ao processo de representação, mesmo quando este já não remeta a referentes reconhecíveis. A mimesis, entendida não como mera imitação, cópia (sentido hegemônico modernamente), mas como produção que se constitui ontologicamente com identidade própria, será sempre a apresentação de algo que anteriormente inexistia, ou que só havia em potência, e agora se instaura, ou se repete, no sentido de suceder no tempo essa latência anterior, concreta ou imaginária, e se materializa diante dos nossos olhos como se fosse a própria natureza a fazê-lo.

\section{Referências bibliográficas}

ARISTÓTELES. Poética. Tradução, prefácio, introdução, comentário e apêndice de Eudoro de Sousa. Lisboa: Imprensa nacional-Casa da Moeda, 2008.

CRAIG, E. Gordon. Scene. London: Oxford University Press, 1923.

DEBORD, Guy. A Sociedade do Espetáculo - comentário sobre a sociedade do espetáculo. Rio de Janeiro: Contraponto, 1997.

DIDEROT, Denis. Discurso sobre a Poesia Dramática. São Paulo: Cosac Naify, 2006.

FLUSSER, Vilém. "Line and Surface", Writings, Adreas Ströhl, (Ed.), Minneapolis/London: University of Minnesota Press, 2002.

MARINIS, Marco De. Lo spettacolo come texto 1. Versus, 21, set-dez, 1978, p.67.

"Lo spettacolo come texto 2", Versus 22, jan-abr 1979.

PLATÃo. A República. Tradução de Ana Lia de Almeida Prado. São Paulo: Martins Fontes, 2006.

RAMOS, Luiz Fernando. O Parto de Godot e Outras Encenações Imaginárias: A Rubrica como Poética da Cena. São Paulo: Hucitec, 1999.

SCOTT, Gregory. The Poetics of performance - The necessity of spectacle, music and dance in Aristotelian tragedy. In: Performance and authenticity in the arts. Cambridge: Cambridge University Press, 1999.

SHAW, Mary Lewis. Performance in the texts of Mallarmé: The Passage from Art to Ritual. Pennsylvania: Pennsylvania State University Press, 1993. 